\begin{tabular}{llll} 
ZAPISKI HISTORYCZNE & $\underset{\text { Zeszyt } 3}{\text { TOM LXXI }}-$ ROK 2016 \\
\hline
\end{tabular}

http://dx.doi.org/10.15762/ZH.2016.68

PIOTR KITOWSKI

(University of Gdańsk)

\title{
THE ALLEGATION OF WITCHCRAFT AS AN INSULT IN THE JUDICIAL PRACTICE IN A SMALLER TOWN OF THE ROYAL PRUSSIA IN THE SECOND HALF OF $17^{\mathrm{TH}}$ AND $18^{\mathrm{TH}}$ CENTURIES $^{*}$
}

Key words: the Chełmno law, witches, calumny, slander, judicial practice, Nowe nad Wisła

In the mid $-17^{\text {th }}$ century, in Komorsk, situated in the estate of Nowe on the river Vistula, five women were accused of practising witchcraft. Eventually, two of them were burnt at the stake, another two were acquitted, and one died during incarceration. ${ }^{1}$ In July of 1719, in Nowe, a certain Anna Szpornawska was subjected to the "ordeal of cold water." 2 The result of the test, performed three times, proved unfortunate for the woman, and she paid for it with her life. ${ }^{3}$ In November the same year, in Płochocin, located 13 kilometres away, three witches were sentenced and subsequently burnt at the stake. In theory, their death put an end to that case, although a few years later, in 1726, a rumour went around that during the trial the three women named too Małgorzata Drużacka, the wife of an innkeeper from a nearby village. Soon after that, the woman's husband, Jakub, appeared before the Nowe lay justice court. Defending his wife's good name, he implored to verify the case file allegedly containing the three women's statement accusing her of witchcraft. ${ }^{4}$ The

* This article is an English version of the article which appeared in "Zapiski Historyczne", vol. 81, 2016. Translation was part of the task "The publication of 'Zapiski Historyczne' in the English language version, Vol. 81, 2016, books (zeszyt 1-4)" financed as part of the agreement 698/P-DUN/2016 with the resources of the Ministry of Science and Higher Education devoted to the popularization of science.

${ }^{1}$ A woman called Śmietanka, acquitted during this trial, was in 1658 wrongly accused of assisting in a suicide of another accused woman by supplying her with poison. Additionally, a cotter from Komorsk accused her of spreading leprosy and causing or contributing to a miscarriage of a woman from nearby Bzów. Two out of three witnesses confirmed that she was not among those named witches; Archiwum Państwowe in Bydgoszcz [State Archive in Bydgoszcz], Akta miasta Nowego [Nowe city acts] (further cit. APB), no. 196/70, pp. 266-267.

${ }^{2}$ Ibid., no. 196/23, p. 149. At the same time the starost of Nowe, Jakub Zboiński (1710-1752) arrested Władysław Grąbczewski’s wife, who had been named four times, ibid., no. 196/93, p. 98.

${ }^{3}$ Ibid., no. 196/93, pp. 101-103.

${ }^{4}$ Ibid., no. 196/96, pp. 34-35. 
jurors, Stanisław Kuczora, Krystian Trytt and Kazimierz Czajka reached, therefore, for the records of the trial. Finding no proof of guilt in the protocols, at Jakub Drużacki's request, they made an entry in the jury book confirming lack of record and thereby clearing the innkeeper's wife's good name.

The aim of this paper is to analyse the crime of calumny in cases in which the accusation of witchcraft was made in the town of Nowe upon Vistula. A decisive argument for choosing this particular place is the fact that we are in possession of a very well preserved town archive. Aside from minor gaps, the archive is almost complete and one can find there several dozen similar proceedings, the very number of which allows us to verify thus obtained findings, and to determine the actual judicial practice. It appears worthwhile to analyse both the legal norms protecting a person's good name and their application, as well as the catalogue of penalties imposed for slander. Outside of the author's interest, however, lie the issues of witchcraft trials in Nowe, their background and course of proceedings, all of which have been relatively recently presented by Jacek Wijaczka. ${ }^{5}$

On the one hand, the Kulm (Chełmno) law demanded that witchcraft be severely punished. ${ }^{6}$ On the other hand, it protected a person's good name and honour by allowing to defend oneself at court against untrue allegations, as well as to seek compensation of different kinds from the slanderer ("the return of integrity"). ${ }^{7}$ Just like in the Middle Ages, the early-modern society treated honour as one of the most valuable personal properties. Its influence was visible not only in relation to the subject's legal situation, especially when it came to persons of bad reputation,

${ }^{5}$ Jacek WiJaczKa, Polowanie na czarownice i czarowników w Nowem nad Wisłą i najbliższej okolicy miasta w XVII i pierwszej połowie XVIII wieku, Czasy Nowożytne, vol. 22: 2009, pp. 119-144. According to the author's calculations, in the period mentioned, at least 27 trials took place. The total of 38 people were tried, 17 of whom were sentenced to death. For comparison purposes, for moderntime Danzig, in the 200-year period between 1558-1783, there are records of 30 cases involving offences against God and religion, 15 of which pertained to witchcraft charges and ended in convictions (this constitutes only $0,5 \%$ of all common offences). We do not know, however, the number of cases and charges of witchcraft which did not lead to a conviction (Dariusz Kaczor, Przestępczość kryminalna $i$ wymiar sprawiedliwości w Gdańsku w XVI-XVIII wieku, Gdańsk 2005, pp. 158-159). Data relating to witches' trials in Nowe is contained primarily in collections no. 1 and 131, and it is supplemented by mentions in the Council's and Jury's municipal books. The latter suggest that cases of that kind might have been more numerous in Nowe and its vicinity. It is difficult to indicate what their outcome was since the material contained in the Council's and Jury's books does not constitute a full record of the proceedings.

${ }^{6}$ Prawo starochełmińskie 1584 (1394), ed. Witold MaIsel, Zbigniew ZdrójKowski, trans. Andrzej BzDĘGA, Alicja GACA, Toruń 1985, p. 164 (book V, art. 67: “O czarownikach i czarownicach”); Rewizja lidzbarska prawa chetmińskiego 1566 [1711], trans. Andrzej Groth, Koszalin 1997, p. 245 (book V, art. 67: “O czarownikach i czarownicach”); Rewizja nowomiejska prawa chełmińskiego 1580 (1814) zwana także ius culmense emendatum lub ius culmense polonicum, ed. Zbigniew ZDRójKOWsKI, trans. Irena Malinowska-Kwiatkowska, Janusz Sondel, Toruń 1993, p. 50 (book V, art. 63: “O czarownikach i guślarzach”); Ius Culmense ex ultima revisione oder das vollständige Kulmische Recht, hrsg. v. Michael Christoph Hanow, Danzig 1767, pp. 224-225 ("Von Zauberey und Zauberern").

${ }^{7}$ APB, no. 196/101, pp. 169-170 (1742). 
but above all it played a significant role in the stratification of a person in a given community. It enabled one to fully participate in public life, to take office, and to perform a guild profession, and it also played an important role when matrimony was arranged. The loss of honour, through either one's own misdeed (such as personal misconduct, committing crime or performing an indecent profession), or somebody else's (for example a crime committed by a member of one's closest family) resulted in the limitation of the person's previous status. ${ }^{8}$ In extreme cases it led to their marginalisation in the community, while it was fully understood that a good name was easier lost than regained. Of special significance were calumnies which contained an accusation of a crime, among others of witchcraft. Not only did they put one's honour at stake, but additionally they could result in a trial, in the use of torture to extract testimony, or even in the death penalty. The fate of the local witches was widely known, such as the case of Katherine Dekarka (the Roofer), recorded in archives of the village of Skarszewy nearby Tczew. ${ }^{9}$ We owe the account to priest Rajmund Janowski, who witnessed the proceedings (1697). The accused was to recount to him that after being made to drink liquid manure, and being subjected to torture "[...] she had but no choice to say what she did out of torments." She thus pleaded guilty and named other women, allegedly practising witchcraft. The reward for doing so were only two, instead of three, cycles of torture which the law allowed. But when facing her death, she decided to confess the truth. ${ }^{10}$ At the stake, she claimed both herself and the other accused women

\footnotetext{
${ }^{8}$ See e.g. Paweł A. Jezionski, Margines społeczny w dużych miastach Prus i Inflant w późnym średniowieczu i wczesnych czasach nowożytnych, Torun 2009 (there, an indication of present-day literature relating to city underclass); Johanna RicкмAN, Love, Lust, and License in Early Modern England. Illicit Sex and the Nobility, Bodmin 2008; Julius R. RufF, Violence in Early Modern Europe 1500-1800, Cambridge 2004; Jacques Heers, Family Clans in the Middle Ages. A study of political and social structures in urban areas, trans. by Barry HERBERT, Amsterdam 1977.

${ }_{9}^{9}$ Archiwum Państwowe in Gdańsku [State Archive in Gdańsk], Akta miasta Skarszew [Skarszewy city acts] (further cit. APGd), no. 520/21, p. 158.

${ }^{10}$ It comes as no surprise then that having learnt about the slander some of the women fled their towns and villages. The case of a sheepherder's wife from the Tuchola starosty seems of significance here (year 1667, APB, no. 196/75, pp. 601-602). Upon hearing that she was named, she left for an unknown destination. Her husband vouched for her innocence, pleading with the chamberlain of Malbork, Jan Piotr Tuchołka for granting her a safe return home. The family emphasized that the woman, not mentioned by name, who had named the shepherdess did so under duress, and additionally, in the 20 years when the married couple tended their farm the starosty had been free of plague. Eventually, the chamberlain granted the request and the woman returned. Also, in 1700, a certain Anna Zdrojewska fled from Skarszewy to Danzig after being accused of contacts with the devil. When caught and questioned as to why she had done so, she put her action down to foolishness (Jacek WijaczKa, Procesy o czary przed sądami miejskimi $i$ wojewodzińskimi w Skarszewach $w$ końcu XVII i w pierwszej połowie XVIII wieku, [in:] Prusy i Inflanty między średniowieczem a nowożytnością. Państwo - społeczeństwo - kultura, ed. Bogusław Dybaś, Dariusz MakiŁŁa, Toruń 2003, p. 91). In extreme cases, people would even break out of prison, as was the case of Elżbieta Jakuba, who in 1655, having no evidence against her accusation of witchcraft, escaped from custody, having
} 
not guilty. ${ }^{11}$ The above shows, therefore, that there was a very explicit threat that more or less direct insinuations of contacts with the devil, under certain circumstances, such as a witchcraft trial being conducted in the town, could lead to tragic consequences. That was why many victims of slander chose to take legal action to forestall the threat of the loss of honour and the prospective trial.

This was made possible thanks to the Kulm law (ius culmense), which was in force in the province, and above all its $16^{\text {th }}$ century collections. They recognized the crime of calumny (calumnia) insult, treated as an attack against honour. The former amounted to an unfounded allegation made either in the court of law or outside of it; the latter was defined as the use of abusive language against a person. ${ }^{12}$ Clear regulations, however, were never formulated, and differentiating between the two posed significant practical difficulties for judicial authorities, especially in smaller towns whose staff usually lacked adequate legal training. ${ }^{13}$ Hence, on numerous occasions, the two terms were applied interchangeably, with the same legal basis being quoted, and a similar range of punishments, of comparable gravity, being ordered. ${ }^{14}$ But it was not only the classification of the act that may have given rise to doubt. Revisions failed to delimit clearly even the basic issue of court competence. The matter was not helped by sources particular, the aim of which, at least theoretically, was to complement the rules of customary law. "Statutes" (Willkür) law and other small town resolutions did not, as a general rule, pertain to crimes against honour. There were, however, exceptions. Take for example the 1599 Statute of Tczew, which in Article 142 stipulates that "those who deliberately and knowingly encroach upon a man's or woman's honour, disparage and defame them, and will be taken to court for doing so, upon finding the accused persons

previously named several other people whose proceedings continued after her disappearance (APB, no. 196/70, pp. 95-97).

${ }^{11}$ In Nowe, the instance of torture used against Jerzy Marocki in 1754 was widely commented on. A certain townswoman spread the news that the jurors "[...] had his gut ripped out." At the same time she complained of the conditions in which the tortured were kept, claiming that the local court did not have at their disposal a (torture?) chamber like the one in Chełmno, while executioners in other towns would give the accused a day or two of respite between the cycles of torture, which was not practised in Nowe. In this case the calumny against the court was not proven, but for spreading information in inns regarding the workings of the jury the woman was sentenced to a day in the tower and four pounds of wax to be donated to the local parish church (APB, no. 196/32, p. 43).

${ }^{12}$ Danuta Janicka, Prawo karne $w$ trzech rewizjach prawa chetminskiego $z$ XVI wieku, Toruń 1992, pp. 125-129.

${ }_{13}^{13}$ Piotr Kiтowsкi, Wymiar sprawiedliwości w mniejszych miastach Prus Królewskich w II połowie XVII i w XVIII wieku (województwo pomorskie). Z problematyki ustroju sądowego miast Europy Środkowo-Wschodniej we wczesnej nowożytności, Gdańskie Studia Prawnicze. Sprawiedliwość, vol. 35: 2016, pp. 164-170.

${ }^{14}$ As in the case of Nowe citizens of the name Szpyc in 1734. For "[...] calumnating nastily" a certain Franciszek Szenek, they were sentenced to 20 mulcts or a week in the tower, and a public apology to the plaintiff. In case they should be found throwing insults again, they would have had to pay 30 florin (fl.). The court applied the regulation from book V, title 20 (cap. 1) of Rewizja Toruńska pertaining to slander (Ius Culmense, p. 254) (APB, no. 196/98, pp. 161-168). 
innocent, will be under obligation to withdraw the accusations publicly at court, and will be punished by severe incarceration." If the case was dealt with by the council "then the perpetrator should pay consequential damages to the injured party, a hefty fine or be punished by incarceration." ${ }^{15}$

As shown by source materials, apart from indicating the kind of penalties imposed, the regulations of the Tczew act illustrated the practice regarding court competences, employed in Nowe as well. ${ }^{16}$ In that town, complaints were brought before the first or second town assembly (Ordynek), which decided the validity of the plaint, conducted appropriate proceedings, determined the penalty and delivered a ruling. Alternatively, a trial, especially one concerning a minor insult, was referred from the council to the jury, or, vice versa, in cases of greater significance, the first town assembly decided on complaints brought in front of the second assembly. ${ }^{17}$ This phenomenon can be partly attributed to the fact that the competences of early-modern judicial authorities were not clearly determined, and it was observed both in small towns and big Prussian cities like Gdańsk (Danzig) or Torun (Thorn). ${ }^{18}$ The division of competences in the Nowe judicial system did not become more pronounced until the $18^{\text {th }}$ century, when calumny cases were mostly decided by the lay justice court. In that system the council constituted the second instance, which the parties appealed to in the case of an unfavourable ruling. Alternatively, if it was the first assembly which investigated the case, the appeal was then brought directly before the starost, who was exclusively competent to change its ruling. ${ }^{19}$ There is no evidence in the sources, however, for the starosty passing verdicts in the objective proceedings.

The beginning of a witchcraft calumny proceeding was the slanderous use of "you witch" or "you wizard," uttered publicly or in the privacy of one's home, that the slandered learnt about. In Nowe or other small towns, the use of such terms was nothing out of the ordinary, since appellations of this kind were commonly used by the townsfolk, and were a staple of the whole repertoire of insults and various other terms of abuse. For instance, on 21 November 1661, a certain Dosia

${ }^{15}$ Wielki wilkierz królewskiego miasta Tczewa z 1599 roku, ed. Tadeusz MACIEJEwski, Gdańsk 1994, p. 28.

${ }^{16}$ The statute of Nowe did not survive. It can be reconstructed only by referring to particular regulations contained in the city books. See more Piotr KiтowsкI, Sukcesja spadkowa w mniejszych miastach województwa pomorskiego w II połowie XVII i XVIII wieku. Studium prawno-historyczne, Warszawa 2015, pp. 43-45.

${ }^{17}$ APB, no. 196/26, pp. 58-59 (dishonouring the city mayor, 1730).

${ }^{18}$ Zygfryd Rymaszewski, Sprawy gdańskie przed sądami zadwornymi oraz ingerencja królów w gdański wymiar sprawiedliwości XVI-XVIII w., Wrocław 1985, p. 12; Krystyna KamińsKa, Sadownictwo miasta Torunia do połowy XVII w. na tle ustroju sądów niektórych miast Niemiec i Polski, Warszawa 1980, p. 75. Comp. Marian Мıкоєајсzук, Proces kryminalny w miastach Małopolski XVI-XVIII wieku, Katowice 2013, pp. 61-87.

${ }^{19}$ P. KIтоwsкi, Wymiar sprawiedliwości, pp. 156-157. On the relations of the Nowe city authorities with starosts and issues concerning judicial competences: idem, Spory rady miejskiej Nowego nad Wisłą ze starostami w XVIII wieku, Czasy Nowożytne, vol. 28: 2015, pp. 111-127. 
Dorota Cielowa faced at the council a wench from Nowe, ${ }^{20}$ throwing "indecent" insults that the former practised witchcraft. She brought to the session two witnesses, carpenters Jan Karkowski and Paweł Balik. Both confessed that they had been told by a certain Hanna and her friend, walking with other young girls from Osiek to Nowe, that the council ordered to burn Cielowa at stake but for reasons unknown renounced the decision. ${ }^{21}$ Also, on 27 August 1683, a Józef Dalaniemiec appeared before the lay justice court, defending his wife who had been slandered by Andrzej and Katarzyna Mazurowicz, nee Walknecht, to be a "sorceress and a witch."22 On the same day, Krzysztof Żorawski sued before the court Jan Zez, who had allegedly forced his way into the plaintiff's house, and using gross words insulted his wife and mother, additionally threatening to attack them physically. ${ }^{23} \mathrm{He}$ accused the women of prostitution and also of "being possessed by the devil." Next, in December 1730, town councillor Kasper Langa sued the Kuczoras, as according to his account, Stanisław Kuczora had threatened him with a knife, and then, to make matters worse, the ruffian's wife paid him a visit, calling him a thief and a wizard. Those events might have stemmed from longstanding lawsuits. ${ }^{24}$ Finally, violence was at the core of another complaint, against Marcin and Anna Hamulec (?). In October 1749 , the two decided to extort an outstanding debt of 14 florin from a certain Antoni Łaszeński. The lenders visited the debtor at his house and, disregarding his objections, took to seize equipment and other stock, such as bed linen, the cart and the harrow, towards the repayment of the liability. Laszeński, protesting the unlawful execution, was beaten up, while his wife was called a witch. ${ }^{25}$

The majority of these lawsuits were neighbourly disputes, involving different degrees of violence, which frequently originated from financial arguments or the infringement of property law. It is further illustrated by the case of Zofia Kucharka. The case was heard in April 1742, and pertained to the charge of practising witchcraft, including an attempt to poison and bring serious illness upon the coachman of the local Bernardine monastery. Kucharka called several people before the court, who without hesitation confirmed her innocence. The plaintiff, the ill

${ }^{20}$ APB, no. $196 / 70$, pp. $475-476$.

${ }^{21}$ An entry of 1746 has a similar factual status. A shepherdess from the parson's domain, Marianna Krakowska accused several town housemaids of calumny. According to witnesses, the girls were on their way back from Skórcz, where a trial against witches was being held at the time. When asked about those events, they claimed that not only Skórcz but also Nowe "[...] is full of witches dwelling on priestly land." At the same time they pointed at the shepherd's house. When queried if anybody from Nowe had been named, they suggested that two women from the parson's domain might have been. The magistrate requested the case files from Skórcz (APB, no. 196/104, pp. 81-83).

${ }^{22}$ APB, no. 196/76, p. 316.

${ }^{23}$ Ibid.

${ }^{24}$ Ibid., no. 196/97, p. 148.

${ }^{25}$ Ibid., no. 196/105, pp. 14-15. Comp. also Irena ZalewsKa, Sprawy obyczajowe przed sadami miejskimi małych miast kaszubskich w XVII i XVIII wieku na przykładzie Skarszew i Kościerzyny, [in:] Szkice z dziejów Prus Królewskich XVI-XVIII wieku. Gospodarka, społeczeństwo, kultura, ed. Józef WŁODARSKI, Gdańsk 2008, pp. 143-146. 
coachman's wife Helena, eventually confessed “to have been talking impatiently, meaning enviously." ${ }^{26}$ The root of the envy was the fact that several years earlier the slandered woman had been hoping to marry the coachman. She failed to do so since he married the said Helena. Had he not done so, now Kucharka would be obliged to look after the ailing coachman. The court, viewing the statements as "drivel," called upon the women to make apologies, warning at the same time against any further mayhem. Also, in October 1723 the Nowe mayor Michał Żorawski was accused of calumny by the juror Krzysztof Trytt. Żorawski publicly named him a wizard, following a neighbourly dispute, which carried onto office matters, namely refusing permission to build property next to the mayor's house, as well as an earlier witchcraft accusation which Żorawski directed at Trytt. ${ }^{27}$

Despite its distinctive character, the crime of calumny involving the accusation of witchcraft was dealt with by courts like common forms of discrediting somebody's honour. In accordance with the procedure, the two parties appearing before the court had to give evidence for their statements. The party accused of slander

\footnotetext{
${ }^{26}$ APB, no. 196/101, p. 58.

${ }^{27}$ Ibid., no. 196/95, pp. 79, 83. During a fair in 1719 Żorawski was vilified by Maciej Kraffert.
} While the latter was out, the mayor visited his house, and noticing a violin on the wall, reached for it and started to play. He was thus found by the house owner, who, upset, took to calling him a thief and a wizard (ibid., no. 196/93, pp. 53, 62-65). In 1725 Żorawski stood in front of the court as plaintiff again, after a townswoman Agnieszka Grzęmska insulted the mayor by telling him that "[...] your sisters are witches." She was ready to prove the witchcraft accusation in court ("[... if you want, take me to court and I will stand fast"). At the same time she reminded that the official's mother and one of his sisters were burnt at stake (ibid., no. 196/95, pp. 277-278; the defendant's last will of 1731: ibid., no. 196/98, pp. 144-145). Next, in 1742 mayor Kazimierz Czayka sued Michał Kwiatkowski, a juror, who allegedly claimed that Czayka could not have been elected to his office in Nowe since he came from "a family of witches." Also, he suggested that Czayka was corrupted ("could be bought"). He ended up being sentenced to several mulcts (ibid., no. 196/101, pp. 92-97, 98-102). Later, in 1750, the mayor's wife, Anna Czayka, sued Jan Żurawski. The woman was insulted by being called "a witch". Witnesses confirmed having heard Żurawski's wife say to Anna Czayka that she "counted her a witch." The woman retaliated. It was suggested that Żurawska had been expatriated from Golub (due to witchcraft accusations?). In this case, it was even decided that the two parties should be called on to present substantive evidence relating to the expatriation (ibid., no. 196/106, pp. 41-46, 54). Also, a night of card playing at the house of Kasper Langa, a juror, ended up in witchcraft insults when the fun was interrupted by the wife of one of the participants, Jan Moldon. The woman urged her husband to return home but the man showed no inclination to do so. Instead, he started to accuse the wife of another participant in the gathering, Michal Jungnikiel, of inciting his wife and other women in town, saying "[...] she is a ringleader to all of them townswomen, [...] stirring them to keep a tight rein, [...] so to her you can turn now, to the beast, as it is the Jungnikiel woman who cocks a snook at her husband and stirs you like a devil." What was initially a peaceful exchange, turned into a brawl involving a lot of verbal abuse (ibid., no. 196/93, pp. 124-125). Next, in 1702 in Skarszewy, a court case against a certain Parzyńska was underway. The conflict was triggered by an unlawful seizure of a horse. During a confrontation between the alleged thief and the animal owner both parties vituperated each other, including accusations of witchcraft. The argument rebounded on the plaintiff's husband as well, who was told to "[...] keep your gob shut, you harbinger who plays at witches' Sabbaths" (APGd, no. 520/7, book 86-86v). 
was obliged to prove the plausibility of practising witchcraft by the plaintiff, while the plaintiff could defend their innocence by calling witnesses or using other evidence materials, such as an oath. ${ }^{28}$ If the party accused of slander failed to prove any witchcraft activity on the part of the plaintiff, or if they pleaded guilty of calumny, they were then pronounced guilty and an appropriate sentence was passed.

Records of court cases show that the penalties adjudged were of various character and tended not to be too oppressive. They usually came down to having to publicly withdraw the calumny and apologize to the plaintiff, pay a small fine and reimburse the court expenses, such as fees and travel costs. It was only in the case of not carrying the court's ruling that an additional or alternative punishment was decided, in the form of a higher fine and a temporary imprisonment in the town hall tower. Such was the case with the squabble between Andrzej Grabowski and Karol Jungnikiel in 1742, which included a suggestion of witchcraft practices. When the former offended his interlocutor's mother, the latter responded that " $[\ldots]$ it is your mother who is a slut and a witch," which led to a brawl. All the same, Grabowski by means of legal proceedings demanded that the slanderer prove the witchcraft accusations, which he was unable and unwilling to do. He was therefore sentenced to a fine of three mulcts and two hours in the town hall tower. ${ }^{29}$ By comparison, for lashing Jungnikiel with a cane several times, Grabowski had to pay four mulcts to the victim and another two to the court. ${ }^{30}$ However, the lay justice court was less

${ }^{28}$ Recently the issue of oath in civic and landed law in Royal Prussia was dealt with by Piotr Kitowski, Przysiega dowodowa w polskim prawie miejskim i ziemskim w XVII-XVIII wieku. Model normatywny oraz praktyka sądowa na przykładzie wybranych mniejszych miast województwa pomorskiego i malborskiego, a także sądu grodzkiego w Kiszporku (Dzierzgoniu), [in:] Nil nisi veritas. Ksiega dedykowana Profesorowi Jackowi Matuszewskiemu, ed. Marcin GıuszaK, Dorota WiśnIewsKAJóźwIAK, Łódź 2016, pp. 315-330.

${ }^{29}$ Also, it was stated that "he should have been judged more severely, and as a man in public office he should have let the unwise man's remarks pass over in silence, notably it having happened in a public place and among strangers. At the same time, the court ruled that should a town official of Nowe be insulted in the future, the perpetrator would be punished with a fine of 30 mulcts "since an officer, lawfully and at all times, should be regarded respectfully" (APB, no. 196/101, pp. 166-179). Moreover, a factor considered when a sentence was being decided was the defendant's financial standing. The same year saw a woman named Zborowska, a widow, summoned before the jury. The woman offended Jakub Szmet's wife, questioning her marital fidelity. As recorded, "minding her poverty" she was absolved from financial penalty, subject to 30 mulcts should she be found guilty of calumny again. However, she was to put in an appearance, for a few hours at a time, at the town hall hallway for seven consecutive day, as well as cover the proceedings costs (ibid., no. 196/101, pp. 88-89).

${ }^{30}$ The ruling threw him off balance. He started to scrimmage in the court, for which he was punished with three hours in the tower, and his case was referred to the council. To illustrate the lenience of the sanctions placed on Grabowski, compare with penalties decided in similar cases. For instance, in 1730, when Michał Żorawski and his wife beat up the Spornawskis, he was sentenced to 45 mulcts and two Sundays in the tower, as the defendant, "being a town councillor, should be putting a stop to such barneys instead of starting them, looking to his privilege." His wife, for slapping the plaintiff on his face, was sentenced to a week's custody. They were to leave the tower only after the full amount had been paid (APB, no. 196/26, p. 36). In another incident, in 1713, the mayor of Nowe beat up the 
understanding in 1689 during the case between Anna Lińska and a townswoman of the name Baranowska from Nowe. According to several witnesses, Baranowska was to insult Lińska using foul language and calling her a witch. ${ }^{31}$ When sued, she refused to appear in court. She did not turn up to a hearing, sending her husband instead. She was therefore found guilty of using unsubstantiated defaming "filthy vocabulary," for which she was sentenced to 24 mulcts, half of which went to the court, and the other half to the local parish church to pay for wax. ${ }^{32}$ Additionally, she was obliged to cover all the trial expenses, and the verdict was to be carried out on that very same day. Next, in 1730, Samuel Grunwaldt sued a certain Zawadzińska. The defendant was charged with calumny against the plaintiff's family, having called them "Lutheran dogs, boors and mange." ${ }^{33}$ She later denied having said any of the above, explaining instead that when Grunwaldt's maid came to her to ask for flour, the court case was already on the way, and the Zawadzińskis deemed the woman's visit a common affront. In court, still claiming her innocence, she blurted out: "let that Lutheran give it a rest or three hundred devils will strike him," which in the court's opinion amounted to an offence to honour. As a result, the woman was sentenced to imparting eight pounds of wax to the church, as well as having to apologize to the man's wife and children, and paying court expenses. ${ }^{34}$

Apart from penalties or as a guarantee that the pledged peace should be observed, a security was sometimes adjudged on court cases, and it was imposed on the party which disregarded the provisions of the verdict passed by the court.

town scribe. For 'inflicting pain and crippling' the man, he was sentenced to 15 mulcts, and further ten towards the parish church (ibid., no. 196/22, p. 16). The same year, municipal inspectors were subjected to abuse when surveying forest workers on account of suspected sales of illegal goods. In connection with this incident, Samuel Grunwaldt was sentenced to ten mulcts and a week in the tower (ibid., no. 196/26, pp. 59-60).

${ }^{31}$ On that very same day, Baranowska filed a complaint against Jan Petersz, who, like Lińska, allegedly was guilty of slander (having said "the smartmouth from Danzig"), APB, no. 196/79, pp. 197-198; J. WIJACZKa, Polowanie na czarownice i czarowników w Nowem, p. 119.

${ }^{32}$ APB, no. 196/79, p. 201. In the same case, there later appeared a charge of deliberate perjury on the part of one of the witnesses (ibid., p. 202).

${ }^{33}$ Ibid., no. 196/97, pp. 84-85.

${ }^{34}$ However, much higher amounts were recorded too. For example, on Christmas Day in 1754, in the house of Skarszewy mayor, Piotr Podwels, a townswoman was beaten and insulted by being called a witch. The offenders were Piotr Podwels himself and his son, the local treasurer. For assault and battery, and for Jan's violent participation in the event, he paid the plaintiff five thaler, and another five to the parish church. Additional ten thaler was to be donated towards the erection of the tower, under construction at the time. However, a witchcraft accusation uttered by the mayor was met with a more determined reaction. The council fined him the whole $100 \mathrm{fl}$., for the benefit of the parish church, to be paid no later than within a month (APGd, no. 520/25, books 57-59, 98). For comparison purposes, at the time the amount constituted two annual salaries of a town scribe in Nowe. Comp. APB, no. 196/24, p. 44; no. 196/31, p. 10; no. 196/32, p. 134; no. 196/36, p. 67; Andrzej Pryıowski, Gospodarka Nowego n. Wisła w latach 1662-1772. Problemy produkcji i wymiany, Bydgoszcz 1978, p. 171; Piotr Kitowski, Notarius civitatis w kancelarii miejskiej Nowego nad Wisła w XVIII wieku, Studia z Dziejów Państwa i Prawa Polskiego, vol. 17: 2014, pp. 65-69. 
In several cases, records quote exile as a proposed means of punishment, with no mention, however, of such penalty ever being enforced. For example, in August 1742 , court proceedings against a man named Berezowski were coming to an end. The man was guilty of hurling insults at juror Wojciech Murawski's wife, who objected to his rowdy behaviour. The woman was called names, such as "skunk, witch and slithery worm," and so was her husband. For such calumnies he was sentenced to six mulcts for the court, and six for the insulted parties. Moreover, he was to spend three consecutive days in the town hall tower, with a warning that should he take to trouble making again, he might be exiled. The woman, who retaliated when offended and was found guilty of dishonouring Berezowski in public, was sentenced to two mulcts and made to apologize to the accused. ${ }^{35}$ In another case, in 1730, a townswoman Zawadzińska could have been charged the full amount of 20 thaler by the municipal prosecutor if she had not executed the court ruling. ${ }^{36}$ At the same time, the security was in some cases the result of an agreement between the parties. In November 1745, a feud between Anna Czayka and Anna Hobrzeńska came to an end, after the latter called Czayka a witch. The slandered party demanded therefore that either her guilt be proven, or Hobrzeńska should be punished and made to cover the proceeding costs. ${ }^{37}$ Before the end of proceedings, however, the two parties reached a settlement, stating that they waive legal action and lodge a security of 50 mulcts. If any of the women had caused further trouble, she would have been obliged to pay up and would have faced exile.

If neither of the parties was able to prove their claims, and both were slandering each other, the court tended to order apologies and that "silence be observed" on the case. This usually happened when the knowledge of being insulted reached the alleged victim vicariously, while in reality the accused might not have uttered the calumny, or when the victim possessed no evidence to prove the accused guilty. Such was the case of the proceedings, in September 1680, against Mr and Mrs Jesarz, accused by a certain Engielbrecht (Engelbrecht) of insult, quoting that the couple had been heard saying that the devil "threshed" his wife. ${ }^{38}$ After inter-

${ }^{35}$ APB, no. 196/101, pp. 112-113, 124-125.

${ }^{36}$ The same court procedure was applied in the case of ordinary types of calumny, offences against self-respect, assault and battery, and other minor offences. For example, in 1730, the council was hearing a squabble case between two townswomen, Doroszewicz and Szczepańska. Eventually, both parties were found guilty, and as a result sentenced to one and two pounds of wax respectively to be donated to the parish church, and the women were to apologize to each other. Also, a security of ten thaler and three days in the tower was imposed (APB, no. 196/26, pp. 49-50). Four years later, a security of ten thaler was laid on the sentence in the case of Jakub Szczepański versus a townswoman Swiderska, who called him "a dog" (ibid., no. 196/98, pp. 120-121). In another case, in 1763, a certain Jan Cynka, on account of his "promiscuous life and continuous disputes," was ordered to make peace with his wife. If either of them caused any further trouble, they were warned the sentence would be 50 mulcts and a four-month imprisonment in the city tower on a diet of bread and water only (ibid., no. 196/36, pp. 211-212).

${ }^{37}$ Ibid., no. 196/103, pp. 18, 115-116.

${ }^{38}$ Ibid., no. 196/78, p. 75. 
[503] The allegation of witchcraft as an insult in the judicial practice in a smaller town...

rogating witnesses, and since neither couple were able to evidence their claims, the council ordered mutual apologies, and ten mulcts in case either party should fail to observe the ruling, or should new calumnies be spread. ${ }^{39}$ Thereby both parties were committed to observe eternal silentium.

Summing up, the jury and the council in Nowe heard multiple case concerning the offence of calumny, often involving the accusation of witchcraft. The revision regulations of the second half of the $16^{\text {th }}$ century, as well as particular sources, gave only highly general and imprecise guidelines for how to deal with such charges. They were explicated by court practice. In case of the town of Nowe on the river Vistula, both the trial proceedings and the punishments ruled in such cases, were not different from ordinary calumnies, which filled the protocols in the municipal acts. The punishments ruled by the justice administration usually came down to a public apology to the injured party, the payment of a certain amount of money, occasionally short-term detention, and covering the court costs. It would seem that the pecuniary penalty, a short stay in the tower, or the threat of having to suffer even more serious sanctions, such as paying a security, were effective in keeping the slanderer from re-offending in the future. These were indeed rare situations when the accused stood against the same plaintiff in the court again, or actually was made to pay the security..$^{40}$ When it came to that, however, the securities were fully executed or new more severe pecuniary sanctions were imposed, the aim of which was to curb the "calumnator's" 41 inclinations, and at the same time to atone for the plaintiff's loss of honour.

(transl. by Agnieszka Chabros)

\footnotetext{
${ }^{39}$ Ibid., pp. 81-82.

${ }^{40}$ It remains true, however, that once somebody was accused of witchcraft, or if members of their family had been involved in such proceedings, similar allegations were likely to resurface multiple times, and bad reputation followed them for years to come. The sentences passed had little bearing. The memory of such incidents meant that the good name of the son or daughter, or even their children, could be questioned and they could be considered "of a witch's parentage." The same was true for those acquitted in witchcraft trials, as under adverse conditions the accusations could recur. An alleged witch, Anna Pielecka, acquitted of all charged, did not enjoy her freedom for long. Only two years after the first trial, she was named by another woman accused of witchcraft, Anna Kikowa. According to the entry in the jury books of 31 August 1691, she asked for the test of cold water. During the ordeal, repeated three times, she floated on the river, hence she was deemed a witch, and exiled from the town. If she reappeared in Nowe or the vicinity of the town, she was to be burnt at stake immediately. It was not a unique case (APB, no. 196/82, pp. 141-142). In 1701, Wawrzyniec Jordański swore that a certain townswoman, named by Magdalena Rusek, practised witchcraft. The woman did not pass the cold water test. Despite this, she was acquitted and spared the stake. However, she was named again in 1709 by Ewa Świątek, whose accusations were confirmed by other townsfolk. One of them claimed she was guilty of his child's death. When faced with such charges, the woman pleaded to be given the cold water test. The court acceded to the demand (ibid., no. 196/87, p. 67; no. 196/20, pp. 142-143, 145; no. 196/88, pp. 45, 47-48).

${ }^{41}$ Ibid., no. 196/81, pp. 189-190 (the adultery calumny, 1687).
} 
Received $5^{\text {th }}$ February 2015

Received in revised form $12^{\text {nd }}$ October 2016

Accepted $31^{\text {st }}$ October 2016

PhD Piotr Kitowski

Faculty of Law and Administration

University of Gdańsk

e-mail: p.kitowski@prawo.ug.edu.pl

\author{
DER HEXEREI-VORWURF ALS EHRVERLETZUNG \\ IN DER GERICHTSPRAXIS EINER KLEINEREN STADT \\ IM KÖNIGLICHEN PREUSSEN IN DER 2. HÄLFTE \\ DES 17. UND IM 18. JAHRHUNDERT
}

\title{
Zusammenfassung
}

Schlüsselwörter: Kulmer Recht, Hexen, Verleumdung, Verbalinjurie, Gerichtspraxis, Neuenburg an der Weichsel

Das Kulmer Recht (ius culmense) und andere, zugleich geltende Rechtssysteme schützten den guten Namen. Das kam u. a. darin zum Ausdruck, dass verschiedene Arten von Beleidigungen in Worten (Verbalinjurien) sowie Verleumdungen mit Strafe belegt waren, wenn sie sich nicht beweisen ließen, und dass sie als ernster Angriff auf ein unumstrittenes Rechtsgut galten, die menschliche Ehre. Das galt auch für Verleumdungen wegen Hexerei. Gegenstand des Artikels ist die Urteilspraxis in Verleumdungsprozessen, bei denen es um den Vorwurf der Hexerei ging, in kleineren Städten des Königlichen Preußens (zweite Hälfte 17. Jh.-18. Jh.). Auf der Grundlage eines Konvoluts von Gerichtsakten aus Neuenburg an der Weichsel (Nowe nad Wisłą), werden der Hintergrund, vor dem die falschen Anklagen auftauchten, die Vorgehensweise der Gerichtsorgane und der von den dortigen Gerichten angewandte Strafenkatalog vorgestellt. Dies liefert einen Beitrag für eine breitere Diskussion zum Thema Hexenprozesse in der Provinz Preußen, für die eine umfassende Au. Ereitung dieser Problematik immer noch aussteht, wie auch der Praxis in anderen Teilen der Krone Polen in der frühen Neuzeit.

\section{THE ALLEGATION OF WITCHCRAFT AS AN INSULT IN THE JUDICIAL PRACTICE IN A SMALLER TOWN OF THE ROYAL PRUSSIA I $\mathrm{N}$ THE SECOND HALF OF THE $17^{\mathrm{TH}}$ AND $18^{\mathrm{TH}}$ CENTURIES}

\section{Summary}

Key words: the Chełmno law, witches, calumny, slander, judicial practice, Nowe nad Wisłą

The Chełmno law (ius culmense) and other legal systems in force protected good reputation. It was reflected for example in the fact of penalizing any kinds of verbal insults and slanders (calumny) which were not supported by appropriate evidence; they were treated 
[505] The allegation of witchcraft as an insult in the judicial practice in a smaller town...

as an insult to the legal interest of a human being. It also concerned false allegations of witchcraft. The subject matter of the article is the practice of adjudicating cases concerning slander (calumny) and including the allegation of witchcraft in smaller towns of the Royal Prussia (the second half of the $17^{\text {th }}-18^{\text {th }}$ centuries). On the basis of the judicial files of the town of Nowe nad Wisłą, the author presented the background of false allegations, the model of conduct of the judicial bodies and the catalogue of punishments used by the courts. It constitutes a contribution to a more extensive discussion about trials concerning witchcraft in the Prussian province and other parts of the Polish Kingdom in the early modern period.

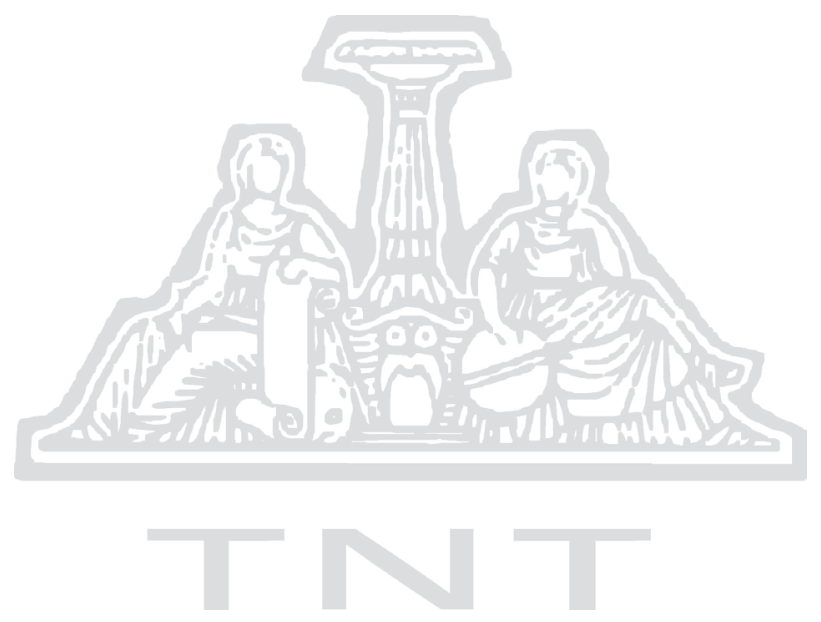

